Note

\title{
Breeding of a new food barley cultivar "Shiratae Nijo" exhibiting no after-cooking discoloration
}

\author{
Takuji Tonooka*1), Naoyuki Kawada ${ }^{1,2)}$, Megumi Yoshida ${ }^{1,3)}$, Toji Yoshioka1), Shunsuke Oda ${ }^{2,4)}$, \\ Koichi Hatta1), Tetsuya Hatano ${ }^{2,3)}$, Masaya Fujita ${ }^{1,2)}$ and Katashi Kubo ${ }^{2)}$ \\ 1) National Institute of Crop Science, 2-1-18 Kannondai, Tsukuba, Ibaraki 305-8518, Japan \\ 2) Lowland Farming Research Station, National Agricultural Research Center for Kyushu Okinawa Region, 496 Izumi, Chikugo, \\ Fukuoka 833-0041, Japan \\ 3) National Agricultural Research Center for Kyushu Okinawa Region, 2421 Suya, Koshi, Kumamoto 861-1192, Japan \\ 4) Present address: National Institute of Crop Science, 2-1-18 Kannondai, Tsukuba, Ibaraki 305-8518, Japan
}

Shiratae Nijo is a new two-rowed food barley cultivar bred at the National Agricultural Research Center for Kyushu Okinawa Region (KONARC) in collaboration with the National Institute of Crop Science (NICS) and released in 2009. Shiratae Nijo is a proanthocyanidin-free cultivar bred by backcross breeding using a leading cultivar Nishinohoshi as a recurrent parent and a foreign proanthocyanidin-free mutant ant28-494 as a nonrecurrent parent. The agronomic characteristics of Shiratae Nijo are almost the same as those of Nishinohoshi which has high yield performance and high resistance to barley yellow mosaic virus (BaYMV) type I and powdery mildew. Like Nishinohoshi, Shiratae Nijo shows high resistance to Fusarium head blight (FHB) at the anthesis stage but is susceptible 10 days after anthesis. Shiratae Nijo exhibits significantly weaker seed dormancy than Nishinohoshi. Shiratae Nijo has excellent pearling quality, and the pearled grains show no discoloration and high whiteness after cooking because of the lack of catechin and proanthocyanidin in the grains.

Key Words: barley, backcross breeding, proanthocyanidin-free, after-cooking discoloration, Fusarium head blight.

\section{Introduction}

Barley is one of the important staple foods in the eastern part of Asia. Barley is used in multiple ways in Japan: as a rice extender, barley tea, and in traditional fermented foods, beer and spirits. In recent years barley has been evaluated as a food throughout the world because of its usefulness as a source of dietary fiber (CFD Report 2005). However, barley grains develop a brown color after cooking such as boiling or steaming, and this discoloration decreases consumer acceptability of barley and thereby hampers its utilization. Recently, many elite barley cultivars with high pearling quality such as Syunrai (Kuwabara et al. 1994), Ichibanboshi (Ito et al. 1995), Nishinohoshi (Sasaki et al. 1999) and Fiber-Snow (Ushiyama et al. 2004) have been bred in Japan; however, no food barley cultivar without after-cooking discoloration has been bred anywhere in the world including Japan. Barley grains contain numerous polyphenolic compounds including catechin and proanthocyanidin in the husks, pericarp, testa and aleurone layers (Aastrup et al. 1984, Nordkvist et al.

Communicated by T. Komatsuda

Received March 18, 2010. Accepted May 10, 2010.

*Corresponding author (e-mail: tohnooka@affrc.go.jp)
1984). Oxidation of phenolic compounds to o-quinones causes discoloration in food (Sapers 1993). The content of polyphenol is positively correlated with the browning degree of the boiled barley grain (Sato 1995, Fujita et al. 2000), but polyphenol oxidase activity is not significantly correlated with the extent of discoloration (Quinde et al. 2004). Proanthocyanidins cause the undesirable colloidal haze in beer (Gramshaw 1970); therefore, many proanthocyanidin-free mutants have been selected in Europe starting more than thirty years ago (Wettstein et al. 1977). Kohyama et al. (2001) demonstrated that the catechin and proanthocyanidin were related to the browning reaction of barley paste after heat treatment. Proanthocyanidin-free mutants have proved to exhibit no or low discoloration after boiling (Tohno-oka et al. 1999); therefore, breeding of food barley with no aftercooking discoloration was started in the Kyushu National Agricultural Experimental Station (KNAES) in 1994 using foreign proanthocyanidin-free mutants, ant13-152 (JendeStrid 1988), Galant (Jende-Strid 1984) and ant28-494 (Jende-Strid 1993). The agronomic characteristics of the primary lines were not sufficient, and rapid improvement of these characteristics was needed to breed elite cultivars in a short period; therefore, Shiratae Nijo was bred by backcross breeding at KONARC in collaboration with NICS. 


\section{Breeding process}

Shiratae Nijo was selected from the cross Izumi-kei A133-3/3 $\times$ Nishinohoshi (Fig. 1). Nishinohoshi is a leading cultivar widely cultivated in the western part of Japan and has high resistance to disease and excellent pearling quality. Izumi-kei A133-3, a proanthocyanidin-free line bred in KNAES in 1997, was selected from the cross between Saikai-kawa 54 (former experimental line name of Nishinohoshi) $\times$ ant28-494 . ant28-494 is a proanthocyanidinfree mutant derived from the European malting cultivar Catrin (Jende-Strid 1993). ant28-494 has a very late maturity and is highly susceptible to BaYMV, which are not adaptable traits in Japan. Backcross and selection of the backcrossed line were performed at NICS from 2001 to 2003. ant 28 is a monofactorial recessive gene located on the long arm of chromosome 3H (Jende-Strid 1993, Garvin et al. 1998). Screening for the ant 28 phenotype was done in $\mathrm{BC}_{2} \mathrm{~F}_{2}$ and $\mathrm{BC}_{3} \mathrm{~F}_{2}$ plants by a vanillin acid test (Kristensen and Aastrup 1986). Fourteen $\mathrm{BC}_{1} \mathrm{~F}_{1}$ plants were grown in the greenhouse and crossed to Nishinohoshi. Nine $\mathrm{BC}_{2} \mathrm{~F}_{1}$ plants were grown in the greenhouse and $80 \mathrm{BC}_{2} \mathrm{~F}_{2}$ plants were grown in the field. A selected $\mathrm{BC}_{2} \mathrm{~F}_{3}$ line containing fourteen plants was grown in the greenhouse and crossed to Nishinohoshi. Fourteen $\mathrm{BC}_{3} \mathrm{~F}_{1}$ plants and $152 \mathrm{BC}_{3} \mathrm{~F}_{2}$ plants were grown in the greenhouse and five $\mathrm{BC}_{3} \mathrm{~F}_{2}$ plants were selected. Three $\mathrm{BC}_{3} \mathrm{~F}_{3}$ lines were transferred to KONARC, and the line selection and yield tests were performed at the research center from 2003. The selected line was designated as Hakei B0801a in 2005, and as Saikai-kawa 65 in 2006. A local adaptability test was conducted at three different stations in 2005. Performance tests for recommendable varieties were conducted at ten different stations in 2006-2008. In 2009, Saikai-kawa 65 was released as Shiratae Nijo and the variety registration was applied to the Ministry of Agriculture, Forestry and Fisheries of Japan. Regional trials are in progress to produce Shiratae Nijo in Northern Kyushu district of Japan.

\section{Agronomic characteristics}

Field data collected at KONARC are described in this

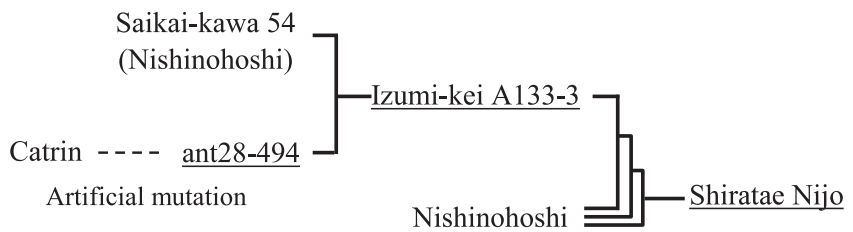

Fig. 1. Pedigree of Shiratae Nijo. Underlines show the lines and cultivar with the ant 28 gene.

note. The agronomic characteristics of Shiratae Nijo are listed in Table 1. Nishinohoshi and Nishinochikara (Tsuru et al. 1990), a previous leading cultivar and the parent of Nishinohoshi, were compared as the check cultivars. All entries were sown in late November. Plots were $4.9 \mathrm{~m}^{2}$ each and arranged in a randomized block design with two replications. The obtained data were evaluated by analysis of variance. The agronomic characteristics of Shiratae Nijo were almost the same as those of Nishinohoshi. Shiratae Nijo had a short culm, about $10 \mathrm{~cm}$ shorter than that of Nishinochikara. The spike length of Shiratae Nijo was slightly longer than that of Nishinohoshi in heavy fertilizer application. No significant differences were observed in the number of spikes or lodging degree among the cultivars. Shiratae Nijo showed highyielding performance, like the check cultivars. The volume weight, 1000-grain weight and percentage of plump grains showed no significant difference among the cultivars.

Resistances to disease are listed in Table 2. Shiratae Nijo showed high resistance to BaYMV type I and V (Sotome et al. 2010), but was susceptible to type III. Shiratae Nijo is presumed to have a resistant gene rym5 derived from Nishinohoshi (Nagamine et al. 2007); therefore, Shiratae Nijo showed the same reaction to BaYMV types as Nishinohoshi. Like Nishinohoshi, Shiratae Nijo had high resistance to powdery mildew. The seed dormancy of Shiratae Nijo is shown in Table 3. Daisen Gold and Kirameki Nijo were compared as highly susceptible and resistant check cultivars, respectively. Shiratae Nijo showed significantly weaker seed dormancy than Nishinohoshi, indicating that the proanthocyanidin-free gene had a negative effect on tolerance

Table 1. Agronomic characteristics of Shiratae Nijo (Means of 2005-2007)

\begin{tabular}{|c|c|c|c|c|c|c|c|c|c|c|c|}
\hline $\begin{array}{l}\text { Fertilizer } \\
\text { application }\end{array}$ & Enrty & $\begin{array}{l}\text { Heading } \\
\text { date }\end{array}$ & $\begin{array}{l}\text { Maturity } \\
\text { date }\end{array}$ & $\begin{array}{l}\text { Culm } \\
\text { length } \\
(\mathrm{cm})\end{array}$ & $\begin{array}{l}\text { Spike } \\
\text { length } \\
(\mathrm{cm})\end{array}$ & $\begin{array}{c}\text { Number of } \\
\text { spikes } \\
\left(/ \mathrm{m}^{2}\right)\end{array}$ & $\begin{array}{c}\text { Lodging } \\
\text { score }^{c} \\
(0-6)\end{array}$ & $\begin{array}{l}\text { Grain } \\
\text { Yield } \\
(\mathrm{kg} / \mathrm{a})\end{array}$ & $\begin{array}{c}\text { Volume } \\
\text { weight } \\
(\mathrm{g} / \mathrm{l})\end{array}$ & $\begin{array}{c}\text { 1000-grain } \\
\text { weight } \\
(\mathrm{g})\end{array}$ & $\begin{array}{c}\text { Plump } \\
\text { grain }^{d} \\
(\%)\end{array}$ \\
\hline \multirow{3}{*}{ Standard $^{a}$} & Shiratae Nijo & Apr. $4 a^{e}$ & May 17a & $92 \mathrm{a}$ & $7.3 \mathrm{a}$ & $615 a$ & $1.2 \mathrm{a}$ & $55.2 \mathrm{a}$ & $712 \mathrm{a}$ & $41.8 \mathrm{a}$ & $79.2 \mathrm{a}$ \\
\hline & Nishinohoshi & Apr. 3a & May $17 \mathrm{a}$ & $93 a$ & $7.3 \mathrm{a}$ & $539 a$ & $0.2 \mathrm{a}$ & $53.3 \mathrm{a}$ & $717 \mathrm{a}$ & $42.9 \mathrm{a}$ & $88.8 \mathrm{a}$ \\
\hline & Nishinochikara & Apr. $4 a$ & May $17 \mathrm{a}$ & $104 b$ & $7.3 \mathrm{a}$ & $533 a$ & $0.7 \mathrm{a}$ & $57.8 \mathrm{a}$ & $721 \mathrm{a}$ & $43.5 \mathrm{a}$ & $83.4 \mathrm{a}$ \\
\hline \multirow{3}{*}{ Heavy $^{b}$} & Shiratae Nijo & Apr. $4 a$ & May $18 \mathrm{a}$ & $93 a$ & $7.5 b$ & $618 \mathrm{a}$ & $1.2 \mathrm{a}$ & $56.9 \mathrm{a}$ & $713 a$ & $42.5 \mathrm{a}$ & $80.5 \mathrm{a}$ \\
\hline & Nishinohoshi & Apr. 4a & May $17 \mathrm{a}$ & $96 a$ & $7.4 \mathrm{a}$ & $671 \mathrm{a}$ & $1.5 \mathrm{a}$ & $58.4 \mathrm{a}$ & $704 a$ & $41.0 \mathrm{a}$ & $76.4 \mathrm{a}$ \\
\hline & Nishinochikara & Apr. 5a & May $17 \mathrm{a}$ & $104 b$ & $7.3 \mathrm{a}$ & $595 a$ & $0.8 \mathrm{a}$ & $58.8 \mathrm{a}$ & $720 a$ & $43.2 \mathrm{a}$ & $78.3 \mathrm{a}$ \\
\hline
\end{tabular}

${ }^{a}$ Basal dressing N-P-K $=0.5-0.64-0.5 \mathrm{~kg} / \mathrm{a}$; top dressing $\mathrm{N}=0.15 \mathrm{~kg} / \mathrm{a}$.

${ }^{b}$ Basal dressing N-P-K $=0.65-0.83-0.65 \mathrm{~kg} / \mathrm{a}$; top dressing $\mathrm{N}=0.3 \mathrm{~kg} / \mathrm{a}$.

${ }^{c}$ Lodging was classified into six degrees (0: no lodging-5: completely lodged).

${ }^{d}$ Whole grain ratio is shown as the percentage of the grains over $2.5 \mathrm{~mm}$ sieving fraction.

$e$ Average values marked with the same letter are not significantly different at 5\% level according to Fisher's PLSD test. 
Table 2. Disease reaction summaries for Shiratae Nijo (2005-2007)

\begin{tabular}{lcccc}
\hline \hline \multirow{2}{*}{ Entry } & \multicolumn{3}{c}{ BaYMV } & $\begin{array}{c}\text { Powderly } \\
\text { mildew }\end{array}$ \\
\cline { 2 - 4 } & Type I & Type III & Type V & RR \\
\hline Shiratae Nijo & $\mathrm{RR}^{a}$ & S-SS & RR & RR \\
Nishinohoshi & RR & S-SS & RR & RR \\
Nishinochikara & RR & MS & RR & RR
\end{tabular}

${ }^{a}$ RR: highly resistant, R: resistant, MR: moderately resistant, M: moderate, MS: moderately susceptible, S: susceptible, SS: highly susceptible.

Table 3. Seed dormancy of Shiratae Nijo (Means of 2005-2007)

\begin{tabular}{llr}
\hline \hline \multirow{2}{*}{ Entry } & \multicolumn{2}{c}{ Germination temperature } \\
\cline { 2 - 3 } & $15^{\circ} \mathrm{C}$ & $20^{\circ} \mathrm{C}$ \\
\hline Shiratae Nijo & $97.3 \mathrm{c}^{a b}$ & $75.7 \mathrm{~b}$ \\
Nishinohoshi & $77.7 \mathrm{~b}$ & $32.0 \mathrm{a}$ \\
Nishinochikara & $84.7 \mathrm{bc}$ & $36.0 \mathrm{a}$ \\
Daisen Gold & $97.3 \mathrm{c}$ & $90.0 \mathrm{~b}$ \\
Kirameki Nijo & $5.0 \mathrm{a}$ & $2.3 \mathrm{a}$ \\
\hline
\end{tabular}

${ }^{a}$ Germination ratio of 100 seeds on the 5 th day of incubation.

${ }^{b}$ Average values marked with the same letter are not significantly different at 5\% level according to Fisher's PLSD test.

to pre-harvest sprouting in barley. Debeaujon et al. (2000) reported that Arabidopsis proanthocyanidin-free mutants exhibited reduced seed dormancy. The reduction of seed dormancy in Shiratae Nijo is presumed to be a negative effect of the proanthocyanidin-free gene. Similar observations were reported in other proanthocyanidin-free barley lines (Nagamine et al. 2006). The wet endurance of Shiratae Nijo was moderate, similar to the check cultivars.

\section{Quality properties}

Pearling time, pearl whiteness and the broken grain ratio were measured as parameters of pearling quality, and the SKCS Index was measured as a parameter of grain hardness. These data are listed in Table 4. There were no significant differences in the SKCS Index, pearling time and broken grain ratio. The pearl whiteness of Shiratae Nijo was the same as that of Nishinohoshi, which was significantly higher than that of Nishinochikara. These data showed that Shiratae
Table 4. Pearling quality parameters of Shiratae Nijo (Means of 2005-2007)

\begin{tabular}{lcccc}
\hline \hline Entry & $\begin{array}{c}\text { SKCS } \\
\text { hardness }\end{array}$ & $\begin{array}{c}\text { Pearling } \\
\text { time }^{a}(\mathrm{sec})\end{array}$ & $\begin{array}{c}\text { Pearl } \\
\text { whiteness (\%) }\end{array}$ & $\begin{array}{c}\text { Broken } \\
\text { grain }(\%)\end{array}$ \\
\hline Shiratae Nijo & $63.3 \mathrm{a}^{b}$ & $695 \mathrm{a}$ & $44.8 \mathrm{~b}$ & $5.3 \mathrm{a}$ \\
Nishinohoshi & $59.9 \mathrm{a}$ & $624 \mathrm{a}$ & $44.5 \mathrm{~b}$ & $5.1 \mathrm{a}$ \\
Nishinochikara & $64.2 \mathrm{a}$ & $738 \mathrm{a}$ & $42.5 \mathrm{a}$ & $4.4 \mathrm{a}$ \\
\hline
\end{tabular}

${ }^{a}$ Time to grind $180 \mathrm{~g}$ of grains to $55 \%$ pearl yield.

${ }^{b}$ Average values marked with the same letter are not significantly different at 5\% level according to Fisher's PLSD test.

Nijo had excellent pearling quality like Nishinohoshi.

The polyphenol content and the discoloration of pearled grain after boiling of Shiratae Nijo are shown in Table 5. The total polyphenol content in grain was much reduced in Shiratae Nijo compared to the check varieties. Grains of Shiratae Nijo contained trace amounts of catechin and proanthocyanidin. The severity of discoloration was expressed by the decrease of whiteness and the increase of the $a^{*}$ value using the 1976 CIE L*a*b* Colour Space (McLaren 1976, a* is the color opponent dimension showing redness). Whiteness was calculated with the following formula: $\quad$ whiteness $=100-\left(\left(100-L^{*}\right)^{2}+a^{* 2}+b^{* 2}\right)^{1 / 2}$. Changes in whiteness and the $\mathrm{a}^{*}$ value of the boiled grains 20 hours after keeping at $70^{\circ} \mathrm{C}$ was much lower in Shiratae Nijo than in the check varieties. Pearled grains of Shiratae Nijo showed no discoloration after boiling (Fig. 2). Cultivars with the proanthocyanidin-free gene would increase consumer acceptability and likely lead to an increase in consumption of barley-based foods. Shiratae Nijo is targeted not only as a rice extender but also for barley bread, barley noodles and as an ingredient of pre-cooked foods.

\section{Resistance to FHB}

The resistance of Shiratae Nijo to FHB is shown in Table 6. Russia 6 and Chevron were compared as the check varieties previously reported as highly resistant varieties (Heta and Hiura 1962, Rudd et al. 2001). Shiratae Nijo showed high resistance to FHB at the anthesis stage, like Nishinohoshi and Nishinochikara. The high resistance at the anthesis stage of these varieties is probably due to their

Table 5. Polyphenol content and discoloration of pearled grain after boiling of Shiratae Nijo (Means of 2005-2006)

\begin{tabular}{|c|c|c|c|c|c|c|}
\hline \multirow[t]{2}{*}{ Entry } & \multicolumn{2}{|c|}{$\begin{array}{l}\text { Total polyphenol }{ }^{a} \\
\qquad(\mathrm{mg} / \mathrm{g})\end{array}$} & \multicolumn{2}{|c|}{$\begin{array}{c}\text { Catechin }+ \text { proanthocyanidin }{ }^{b} \\
(\mathrm{mg} / \mathrm{g})\end{array}$} & \multicolumn{2}{|c|}{$\begin{array}{l}\text { Discoloration of pearled grain after } \\
\text { boiling }{ }^{c}\end{array}$} \\
\hline & Whole grain & Pearled grain & Whole grain & Pearled grain & Whiteness & $a^{*}$ value \\
\hline Shiratae Nijo & $0.79 \mathrm{a}^{d}$ & $0.32 \mathrm{a}$ & $0.05 \mathrm{a}$ & $0.04 \mathrm{a}$ & $-1.4 \mathrm{a}$ & $0.68 \mathrm{a}$ \\
\hline Nishinohoshi & $3.06 \mathrm{~b}$ & $0.74 b$ & $1.33 \mathrm{~b}$ & $0.31 b$ & $-11.0 b$ & $5.30 \mathrm{~b}$ \\
\hline Nishinochikara & $2.93 b$ & $0.81 \mathrm{c}$ & $1.39 \mathrm{~b}$ & $0.38 b$ & $-11.3 b$ & $5.44 \mathrm{~b}$ \\
\hline
\end{tabular}

$a$ Determined by Prussian blue method (Yanagisawa and Amano 1995).

${ }^{b}$ Determined by vanillin method (Burns 1971).

${ }^{c}$ Grains ground to $55 \%$ pearl yield were boiled at $95^{\circ} \mathrm{C}$ for 60 minutes. Discoloration indicates change of color space of the boiled pearled grain 20 hours after keeping at $70^{\circ} \mathrm{C}$.

${ }^{d}$ Average values marked with the same letter are not significantly different at 5\% level according to Fisher's PLSD test. 
Table 6. Severity of FHB of Shiratae Nijo (Means of 2005-2007)

\begin{tabular}{|c|c|c|c|c|c|}
\hline \multirow[b]{2}{*}{ Entry } & \multicolumn{2}{|c|}{ Inoculation at anthesis } & \multicolumn{2}{|c|}{ Inoculation at 10 days after anthesis } & \multirow{2}{*}{$\begin{array}{c}\text { Mycotoxin } \\
\text { concentration } \\
\end{array}$} \\
\hline & Pot-plant method & Cut-spike method & Pot-plant method & Cut-spike method & \\
\hline Shiratae Nijo & $0.7 \mathrm{a}^{c d}$ & $1.0 \mathrm{a}$ & $4.9 \mathrm{a}$ & $4.2 \mathrm{a}$ & $28.4 \mathrm{c}$ \\
\hline Nishinohoshi & $1.9 \mathrm{ab}$ & $1.3 \mathrm{a}$ & $5.5 \mathrm{a}$ & $4.1 \mathrm{a}$ & $26.9 \mathrm{bc}$ \\
\hline Nishinochikara & $0.6 \mathrm{a}$ & $0.6 \mathrm{a}$ & $5.7 \mathrm{a}$ & $4.1 \mathrm{a}$ & $14.7 \mathrm{ab}$ \\
\hline Russia 6 & $2.5 b$ & $0.6 \mathrm{a}$ & $4.3 \mathrm{a}$ & $2.7 \mathrm{a}$ & $3.3 \mathrm{a}$ \\
\hline Chevron & $4.8 \mathrm{c}$ & $1.8 \mathrm{~b}$ & $5.8 \mathrm{a}$ & $3.5 \mathrm{a}$ & $1.5 \mathrm{a}$ \\
\hline
\end{tabular}

${ }^{a}$ Determined by ELISA method (Yoshizawa et al. 2004).

${ }^{b}$ DON: deoxynivalenol, NIV: nivalenol.

${ }^{c}$ Severity is scored as follows: 0: no disease-9: completely diseased.

${ }^{d}$ Average values marked with the same letter are not significantly different at $5 \%$ level according to Fisher's PLSD test.

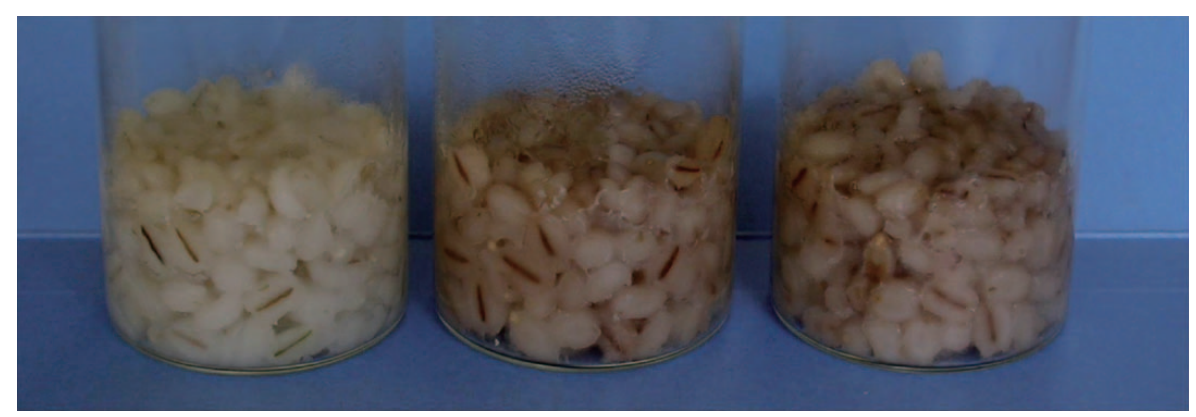

Fig. 2. Boiled pearled grains 20 hours after keeping at $70^{\circ} \mathrm{C}$. From left, Shiratae Nijo, Nishinohoshi and Nishinochikara. Grains ground to $55 \%$ pearl yield were boiled at $95^{\circ} \mathrm{C}$ for 60 minutes.

cleistogamy, which reduces the chance for infection (Yoshida et al. 2005). However, these varieties were susceptible at 10 days after anthesis and accumulated more mycotoxins than Russia 6 and Chevron. Yoshida et al. (2007) reported that the drastic increase in susceptibility to FHB and mycotoxin accumulation in the two-rowed cleistogamous varieties was related to the extrusion on the spent anthers. Flavone and flavanone are antifungal compounds that inhibit the growth of Fusarium (Weidenbörner and Jha 1993), and Skadhauge et al. (1997) reported that proanthocyanidin-free mutants were more sensitive to Fusarium attack than the wild-type. However, there were no marked differences in FHB severity between Shiratae Nijo and Nishinohoshi. This result suggests that lack of catechin and proanthocyanidin does not always lead to an increase in susceptibility to FHB.

\section{Acknowledgments}

The authors thank the following support staff: Mr. S. Suzuki, Mr. O. Noguchi, Mr. H. Endo, Mr. S. Higashi, and Mr. K. Yamazaki of the National Agricultural Research Center, Ms. A. Sagara, Ms. K. Okada, Ms. M. Morita and Ms. M. Obata of the National Institute of Crop Science, and Mr. M. Yamaguchi, Mr. Y. Okubo, Mr. Y. Kawahara, Mr. K. Miike, Mr. T. Miike, Mr. E. Murakami, Mr. M. Nakashima, and Mr. Y. Kawaguchi of the National Agricultural Research Center for Kyushu Okinawa Region.

\section{Literature Cited}

Aastrup,S., H.Outtrup and K.Erdal (1984) Location of the proanthocyanidins in patterns of barley grain. Carlsberg Res. Commun. 49: 105-109.

Burns,R.E. (1971) Method for estimation of tannin in grain sorghum. Agronomy J. 63: 511-512.

CFD Report (2005) The future of barley. Cereal Foods World 50: 271277.

Debeaujon,I., K.M.Léon-Kloosterziel and M.Koornneef (2000) Influence of the testa on seed dormancy, germination, and longevity in Arabidopsis. Plant Physiol. 122: 403-413.

Fujita,M., K.Takeda, N.Kohyama, E.Domon and Y.Doi (2000) Variation in total polyphenol content and browning reaction after heat treatment in barley. Bull. Shikoku Natl. Agric. Exp. Stn. 65: 9-16.

Garvin, D.F., J.E. Miller-Garvin, E.A. Viccars, J.V. Jacobsen and A.H.D.Brown (1998) Identification of molecular markers linked to ant28-484, a mutation that eliminates proanthocyanidin production in barley seeds. Crop Sci. 38: 1250-1255.

Gramshaw,J.W. (1970) Beer polyphenols and the chemical basis of haze formation. II. Changes in polyphenols during the brewing and storage of beer-The composition of hazes. Master Brew. Assoc. Am. Tech. Q. 7: 122-133.

Heta,H. and U.Hiura (1962) Varietal differences in resistance to head blight, Gibberella zeae (Schw.) Petch. Studies on the disease resistance in barley. XIII. Nogaku Kenkyu 49: 177-187.

Ito,M., N.Ishikawa, E.Domon, Y.Doi, T.Katayama, M.Kamio, I.Kato, R. Yoshikawa and T.Tsutsumi (1995) 'Ichibanboshi', a newly released naked barley cultivar. Bull. Shikoku Natl. Agric. Exp. Stn. 59: 109-121.

Jende-Strid, B. (1984) Coordinator's report: Anthocyanin genes. 
Barley Genet. Newsl. 14: 76-79.

Jende-Strid,B. (1988) Coordinator's report: Anthocyanin genes. Stock list of ant mutants kept at the Carlsberg Laboratory. Barley Genet. Newsl. 18: 74-79.

Jende-Strid, B. (1993) Coordinator's report: Anthocyanin genes. Barley Genet. Newsl. 22: 126-137.

Kohyama,N., M.Fujita and K.Takeda (2001) Correlations between barley constituents and the browning reaction in heat-treated barley pastes. Food Sci. Technol. Res. 7: 297-299.

Kristensen, H. and S.Aastrup (1986) A non-destructive screening method for proanthocyanidin-free barley mutants. Carlsberg Res. Commun. 51: 509-513.

Kuwabara,T., M.Kubota, A.Inokuchi, M.Saito, T.Ushiyama, M.Tanaka, R.Akanuma, K.Izumi and T.Sakai (1994) The new six-rowed barley cultivar "Syunrai". Bull. Nagano Agr. Exp. Stn. 45: 33-40.

McLaren,K. (1976) The development of the CIE $1976(\mathrm{~L} * \mathrm{a} * \mathrm{~b} *)$ uniform colour-space and colour-difference formula. J. Soc. Dyers and Colourists 92: 338-341.

Nagamine, T., M. Yamaguchi, M. Ozeki, T.Sekiwa, M. Watanabe, H.Watanabe, N.Kumekawa, T.Mochizuki, N.Kawada and T.Kato (2006) Quality and agronomic characteristics of promised malting barley lines with proanthocyanidin-free allele. Bull. Tochigi Agr. Exp. Stn. 58: 79-86.

Nagamine,T., M.Amagai, T.M.Ikeda, M.Oozeki, N.Haruyama, T.Kato and T.Soutome (2007) Development and evaluation of DNA markers for Japanese malting barley breeding. Bull. Tochigi Agr. Exp. Stn. 59: 45-54.

Nordkvist,E., A.C.Salomonsson and P.Åman (1984) Distribution of insoluble bound phenolic acids in barley grain. J. Sci. Food Agric. 35: 657-661.

Quinde,A., S.E.Ullrich and B.K.Baik (2004) Genotypic variation in color and discoloration potential of barley-based food products. Cereal Chem. 81: 752-758.

Rudd,J.C., R.D.Horsely, A.L.McKendry and E.M.Elias (2001) Host plant resistance genes for Fusarium head blight: sources, mechanisms, and utility in conventional breeding systems. Crop Sci. 41: 620-627.

Sapers, G.M. (1993) Browning of foods: Control by sulfites, antioxidants, and other means. Food Technol. 47: 75-84.

Sasaki,A., T.Touno-oka, T.Tsutsumi, Y.Doi, N.Kawada and M.Tsuru (1999) New two-rowed barley cultivar "Nishinohoshi". Bull. Kyushu Natl. Agric. Exp. Stn. 35: 71-83.

Sato, Y. (1995) Effect of $\mathrm{pH}$, storage temperature, additives and polyphenols on browning reaction in barley processing. Bull. Fukui Agr. Exp. Stn. 32: 43-50.

Skadhauge,B., K.K.Thomsen and D.von Wettstein (1997) The role of the barley testa layer and its flavonoid content in resistance to Fusarium infections. Hereditas 126: 147-160.

Sotome,T., N.Kawada, T.Kato, T.Sekiwa, H.Nishigawa, T.Natsuaki, K.Kimura, Y.Maeoka, T.Nagamine, S.Kobayashi et al. (2010) The current and new strains of barley yellow mosaic virus (BaYMV) in Tochigi prefecture. Jpn. J. Crop Sci. 79: 29-36.

Tohno-oka,T., M.Ohnishi and Y.Taniguchi (1999) Breeding of lowpolyphenol barley line and the degree of browning after boiling treatment. Rep. Kyushu Br. Crop Sci. Soc. Japan 65: 1-3.

Tsuru,M., N.Kawada, T.Tsutsumi, S.Kitahara, T.Fujii, T.Suzuki and A.Sasaki (1990) New two-rowed barley cultivar "Nishinochikara". Bull. Kyushu Natl. Agric. Exp. Stn. 26: 167-186.

Ushiyama,T., S.Hosono, H.Tabuchi, M.Kubota, T.Kuwabara, N. Tsuchiya, T.Hata, A.Inokuchi, M.Saito, T.Kondo et al. (2004) A new barley cultivar "Fiber-Snow". Bull. Nagano Natl. Agric. Exp. Stn. 48: 11-18.

Yanagisawa,A. and Y.Amano (1995) Degradation of flour color in wheat damaged by rain in Hokkaido. In: Noda,K. and D.J.Mares (eds.) Seventh International Symposium on Pre-harvest Sprouting in Cereals 1995, Center for Academic Societies Japan, Osaka, pp. 19-26.

Yoshida,M., N.Kawada and T.Tohnooka (2005) Effect of row type, flowering type and several other spike characters on resistance to Fusarium head blight in barley. Euphytica 141: 217-227.

Yoshida,M., N.Kawada and T.Nakajima (2007) Effect of infection timing on Fusarium head blight and mycotoxin accumulation in open- and closed-flowering barley. Phytopathology 97: 10541062.

Yoshizawa,T., H.Kohno, K.Ikeda, T.Shinoda, H.Yokohama, K.Morita, O.Kusada and Y.Kobayashi (2004) A practical method for measuring deoxynivalenol, nivalenol, and T-2 + HT-2 toxin in foods by an enzyme-linked immunosorbent assay using monoclonal antibodies. Biosci. Biotechnol. Biochem. 68: 2076-2085.

Weidenbörner, M. and H.C. Jha (1993) Antifungal activity of flavonoids and their mixtures against different fungi occurring on grain. Pestic. Sci. 38: 347-351.

Wettstein,D.von, B.Jende-Strid, B.Larsen-Ahrenst and J.A.Sorensen (1977) Biochemical mutant in barley renders chemical stabilization of beer superfluous. Carlsberg Res. Commun. 42: 341-351. 